\title{
Geographical variation in shell morphology and isoenzymes of Helix aspersa Müller, 1774 (Gastropoda, Pulmonata), the edible land snail, from Greece and Cyprus
}

\author{
MARIA LAZARIDOU-DIMITRIADOU*, Y. KARAKOUSIS $†$ \& A. STAIKOU \\ Departments of Zoology and TGenetics, Development and Molecular Biology, School of Biology, Faculty of Sciences, \\ Aristotle University of Thessaloniki, 54006 Thessaloniki, Macedonia, Greece
}

Geographic variation of shell morphology and isoenzymes of the edible snail Helix aspersa Müller was studied in 24 different regions of Greece and Cyprus. Principal components analysis and cluster analysis showed a geographical trend in seven variable characters examined jointly. Morphological variation between populations was of a sufficient magnitude to create discriminant functions that were able to classify 100 per cent of the cases correctly in only three populations whereas the classifications of the rest varied from 20 per cent to 60 per cent.

For the assessment of the genetic polymorphism 13 enzymic systems with 15 loci and 47 alleles were investigated. Three were monomorphic in all populations. The percentage of polymorphic loci $(\mathrm{P})$ ranged from 33.3 per cent to 66.7 per cent and the mean expected heterozygosity from 0.152 to 0.254 . Significant deviations from Hardy-Weinberg equilibrium were found in most loci in most populations. Polymorphism varied greatly from one population to another, but there was not correlation between morphological and genetic variation.

Spatial autocorrelation in continental populations tended to decrease significantly with increasing distance for several loci. The results found by correspondence analysis and the dendrogram produced by the UPGMA algorithm using Nei's identity (I) showed that the degree of genetic identity was high among the populations studied, apart from the group of N. W. Greek populations. The pattern of genetic diversity seem to be influenced by different forces in continental and island populations.

Keywords: alloenzymes, genetic variation, geographical variation, Helix aspersa, morphology.

\section{Introduction}

Helix aspersa Müller, a terrestrial gastropod that probably comes from the western Mediterranean (Sacchi, 1958) is one of the more successful colonizing snails. Because it is edible, it has been widely introduced by humans to continents (Western Europe and North America) and islands of the temperate and tropical zones (Pilsbry, 1939). It is mainly found in coastal areas. H. aspersa's adaptability is accompanied by intraspecific variability in shell morphology, reproductive system and biological cycle (Chevallier, 1977; Madec \& Daguzan, 1987; Madec, 1989; Albuquerque de Matos, 1989). Its capacity for developmental plasticity has almost surely evolved in response to the unpredictable environments the animals face (Pianka,

*Correspondence.
1988). Helix aspersa is an interesting species for the study of genetic structuring of populations because it has limited powers of dispersal despite its wide distribution, caused mainly by humans.

Selander \& Kaufman (1975) have made a special effort to determine geographic structuring of populations of $H$. aspersa, as assessed by the analysis of several enzyme loci. Applying the method of spatial autocorrelation, Sokal \& Oden (1978) reanalysed the microgeographic genetic structure among colonies of $H$. aspersa on two adjacent 10 -acre blocks in Bryan, Texas, originally studied by Selander \& Kaufman (1975), to make a particularly convincing case for differentiation through genetic drift. Crook (1982) reported that populations of $H$. aspers $a$ in the south of the U.K. were more polymorphic than northern ones for the leucine aminopeptidase (LAP) enzyme system. Bleankey et al. (1989) studied the genetic and pheno- 
typic variation in allopatric populations of $H$. aspersa from the U.K., some European populations and Algeria and concluded that $H$. aspersa from Algeria differed significantly. Madec (1991a) concluded the same for populations of $H$. aspersa from Algeria and France.

A visible polymorphism in shell size has been found in $H$. aspersa among populations coming from the island of Crete and Peloponnesos (Greece) (LazaridouDimitriadou et al., 1983). This polymorphism seemed to be related either to differences in the duration of the drought period in the two regions, or to genetic differentiation or to both. A preliminary survey on the morphological and genetic variation in allopatric populations of $H$. aspersa (M. Lazaridou-Dimitriadou et al., in press), showed that the snails from Crete and Peloponnesos did not differ at the isoenzymic level. However, given that shell size has a genetic component (Cook, 1965; Baur, 1984), it is still probable that allopatric populations that are different in morphology should differ in some genetic aspects or follow a geographic trend taking into account that Greece is divided in two by its mountain range (Pindos mountains) and that the sea separates the continent from the islands. In this paper we examine the pattern of morphological and genetic diversity and consider whether there is some kind of (1) intra- or/and inter- population variation, (2) a cline or correlation in individual characters or enzymes among the populations examined along with the changes of climatic conditions, (3) geographical trend, and (4) relation between the morphology and genetics and between the above and the geography and/or the climate.

\section{Materials and methods}

\section{Sampling}

Twenty-four populations of $H$. aspersa were sampled, totalling 805 adult individuals (three populations from the north-western part of Greece, five from central Greece, seven from Peloponnesos, eight from the Aegean islands and one from Cyprus) (average sample size per population $=30$ ) (Fig. 1). In each sample, the specimens were taken within an area of approximately $400 \mathrm{~m}^{2}$. No samples were taken from an altitude more than $50 \mathrm{~m}$ (except Karytaina, $555 \mathrm{~m}$ ). The specimens were brought alive to the laboratory in cardboard boxes while they were aestivating.

The meteorological data, namely total annual precipitation $(\mathrm{P})$ in $\mathrm{mm}$, absolute maximum annual monthly temperatures $\left(T_{\max }\right)$, absolute minimum annual monthly temperatures $\left(T_{\min }\right)$, mean maximum annual monthly temperatures $(T)$, mean minimum

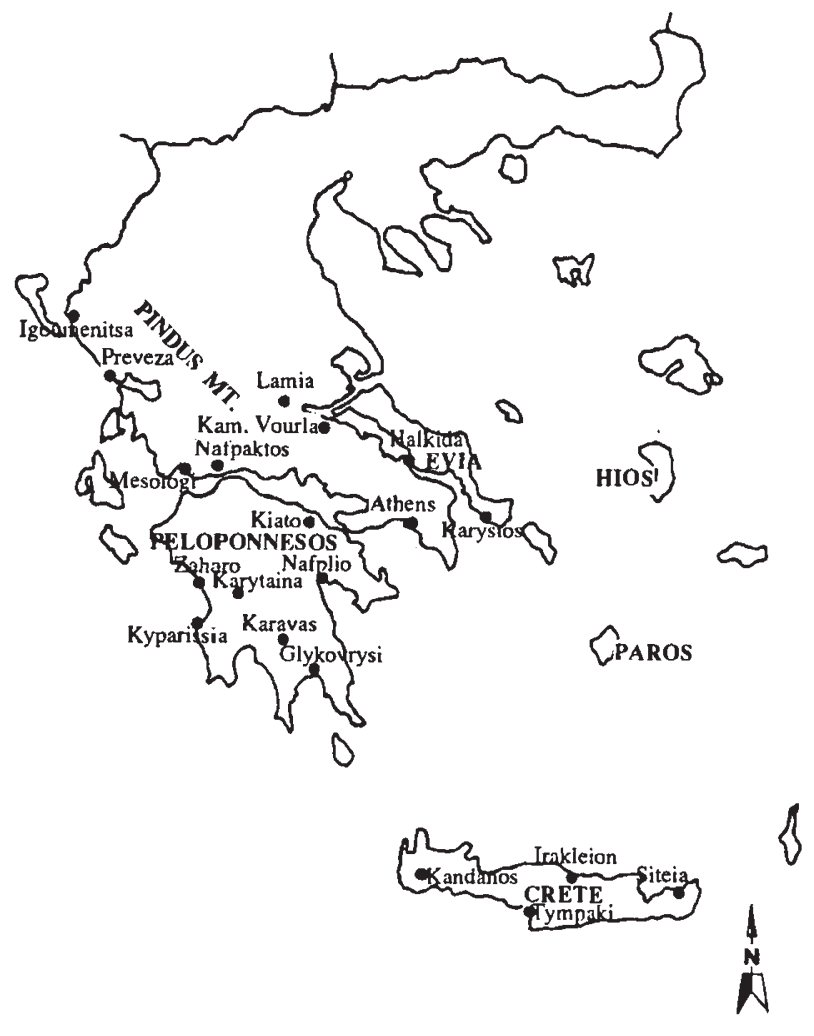

Fig. 1 Sites of samples in Greece and Cyprus. 
annual monthly temperatures $\left(T_{\mathrm{mi}}\right)$, were obtained from the Data Department of National Meteorological Institute of Greece (Table 1). The mean number of days of monthly drought period $(D r)$ and the mean number of days of monthly rainfall $>100 \mathrm{~mm}(\mathrm{Mr})$ were calculated from the ombrothermic yearly curves.

\section{Morphometric data}

Immediately before the electrophoretic analysis the morphometric and qualitative data of the shell were taken.

The snails were weighed $(W)$ to the nearest of 0.001 $\mathrm{g}$ and individually marked on the shell. Shell largest diameter $(D)$, aperture diameter $(d i)$, shell height $(H)$ and shell thickness $(T)$ were measured with a digital calliper to the nearest $0.01 \mathrm{~mm}$. The aperture area $(A p)$ was copied on tracing paper and measured with a planimeter to the nearest of $0.01 \mathrm{~mm}$. The colour was recorded according to Albuquerque de Matos' system
(1984) and number and fusion of bands was also noted. Four classes existed for colour (yellow, brown, red and white), six for the number of bands $(0,1,2,3,4$ and 5 bands) and nine for the fusion of bands (observed combinations of fusion of the existing bands).

\section{Electrophoresis}

The samples for the electrophoretic analysis were prepared from the foot muscle and hepatopancreas (Table 2) (after complete removal of the intestine and washing in distilled water to remove any parasites) (Haralambidis et al., 1985). Tissues were then finely cut and homogenized in equal volumes of $0.1 \mathrm{~N} \mathrm{CaCl}_{2}$, 1.7 per cent sucrose and stored at $-20^{\circ} \mathrm{C}$ for up to 15 days.

For the assessment of genetic polymorphism, 13 enzymes were investigated using starch gel electrophoresis. These enzymes were coded by 15 loci. The buffers and tissue used are shown in Table 2. The

Table 1 Mean yearly meteorological data over 10 years $(1980-90)$

\begin{tabular}{llclcll}
\hline Localities & $\begin{array}{l}T \\
\left({ }^{\circ} \mathrm{C}\right)\end{array}$ & $T_{\mathrm{mi}}$ & $T_{\max }$ & $T_{\min }$ & $\begin{array}{l}\text { Prec. } \\
(\mathrm{mm})\end{array}$ & $\begin{array}{l}\text { Drought duration } \\
\text { (days) }\end{array}$ \\
\hline Igoumenitsa & 26.98 & 9.32 & 37.32 & -2.35 & 975 & 120 \\
Igoumen-2 & 26.98 & 9.32 & 37.32 & -2.35 & 975 & 120 \\
Preveza & 25.72 & 8.66 & 35.2 & 0.036 & 850 & 153 \\
Mesolongi & 27.98 & 9.07 & 37.21 & -0.29 & 373 & 270 \\
Nafpaktos & 28.85 & 9.85 & 37.88 & -2.53 & 726 & 129 \\
Athens & 27.98 & 9.07 & 37.21 & -0.29 & 373 & 114 \\
Halkida & 28.21 & 8.39 & 39.9 & -1.92 & 376 & 207 \\
Karystos & 27.03 & 9.66 & 35.35 & 0.59 & 666 & 198 \\
Lamia & 25.86 & 6.08 & 40.08 & - & 597 & 162 \\
Kam. Vourla & 25.86 & 6.08 & 40.08 & - & 597 & 162 \\
Paros & 25.09 & 10.3 & 35.57 & 1.3 & 423 & 207 \\
Kiato & 27.76 & 8.01 & 39.01 & -0.61 & 476 & 165 \\
Nafplio & 26.85 & 8.33 & 38.43 & -1.1 & 527 & 150 \\
Glykovrysi & 27.12 & 9.84 & 38.4 & -0.28 & 836 & 180 \\
Karavas & 28.88 & 8.88 & 41.38 & -1.74 & 915 & 162 \\
Kyparissia & 25.61 & 10.14 & 35.14 & 0.23 & 762 & 156 \\
Zaharo & 26.63 & 8.96 & 38.13 & -3.23 & 896 & 156 \\
Karytaina & 24.9 & 4.55 & 39.28 & -10.12 & 788 & 126 \\
Kandanos & 28.25 & 11.94 & 39.53 & 3.78 & 311 & 243 \\
Tympaki & 26.21 & 10.63 & 39.91 & 1.43 & 514 & 192 \\
Siteia & 25.82 & 11.16 & 35.13 & 3.23 & 520 & 171 \\
Irakleion & 26.12 & 11.02 & 36.33 & 2.5 & 505 & 150 \\
Hios & 26.56 & 8.98 & 36.1 & -1.5 & 522 & 203 \\
Cyprus & 28.3 & 10.1 & 35.5 & 7.65 & 351 & 210 \\
\hline & & & & & & \\
\hline
\end{tabular}

$T$ : mean maximum annual monthly temperature; $T_{\mathrm{mi}}$ : mean minimum annual monthly temperature; $T_{\max }$ : maximum annual monthly temperature; $T_{\min }$ : minimum annual monthly temperature; Prec.: total annual precipitation in $\mathrm{mm}$. Mean annual drought duration in days (estimated from the drought period of the ombrothermic curve of each region from 1986 to 1990 ). 
Table 2 Electrophoretic conditions and enzymes analysed. The esterase D band only appeared when the gel was stained with the fluorescence method whereas the rest of the esterases were stained with the conventional and fluorescence method as well

\begin{tabular}{lllllc}
\hline Enzyme & Abbreviation & E.C. no. & Locus & Tissue & Buffer \\
\hline Aspartate aminotransferase & AAT & 2.6 .1 .1 & 1 & Hep. & A \\
Esterase & EST & 3.1 .1$. & 2 & Hep. & B \\
Esterase D & ESD & 3.1 .1$. & 1 & Hep. & A \\
$\alpha$-Glycerophosphate dehydrogenase & $\alpha$ GPDH & 1.2 .1 .12 & 1 & Foot & A \\
Glucosephosphate isomerase & GPI & 5.3 .1 .9$. & 1 & Hep. & A \\
Isocitrate dehydrogenase & IDH & 1.1 .1 .42$. & 1 & Foot & B \\
Lactate dehydrogenase & LDH & 1.1 .1 .27$. & 1 & Hep. & C \\
Leucine aminopeptidase & LAP & 3.4 .11$. & 1 & Hep. & A \\
Malate dehydrogenase & MDH & 1.1 .1 .37$. & 1 & Hep. & Hep. \\
Phosphomannose isomerase & PMI & 5.3 .1 .8$. & 1 & Foot & A \\
6-Phosphogluconate dehydrogenase & GPD & 1.1 .1 .49$. & 1 & Hep. & C \\
Phosphoglucomutase & PGM & 2.7 .5 .1$. & 2 & Hep. & B \\
Superoxide dismutase & SOD & 1.15 .1 .1$. & 1 & & \\
\hline
\end{tabular}

A: $0.13 \mathrm{~m}$ Tris, $0.04 \mathrm{~m}$ citric acid, $0.018 \mathrm{~m}$ EDTA, $\mathrm{pH}=7.1$ for gel buffer, $0.13 \mathrm{~m}$ Tris, $0.037 \mathrm{~m}$ citric acid, $0.001 \mathrm{~m}$ EDTA, $\mathrm{pH}=7.1$ electrolysis buffer. B: Ashton et al. (1961). C: Smith (1968). Hep. $=$ hepatopancreas.

alleles were named $(A-E)$ from greater to less mobility. Several esterase loci were present but only two produced zymograms interpretable in Mendelian terms.

\section{Statistical analysis of morphological variation}

The intrapopulation variation was calculated with the coefficient of variation (CV) of all the morphometric characters of the examined populations. For the assessment of the interpopulation variation discriminant analysis (DFA) was used with the SYSTAT (1990) computer program.

To examine geographical variation, the climatic data, morphometric and qualitative data of the shell were subjected separately to principal component analysis (PCA). For PCA analyses the six morphometric characters and the three qualitative ones, mentioned above, were used. Cluster analysis (Sneath \& Sokal, 1963) was also performed on the basis of Mahalanobis (1936) distances based on morphometric data of the 24 populations studied. Morphometric measurements were transformed to their natural logarithms and the effect of size was removed with Burnaby (1966) adjustment, employing the NTSYs computer program (Rohlf, 1990). To test the homogeneity of groups generated by PCA, ANOVA tests and Fisher least significant difference tests (L.S.D.) were performed on the first three factors of PCA. For the climatic variation the seven climatic variables $\left(T_{\max }, T_{\min }, T, T_{\operatorname{mi}}, P, D r\right.$ and $\left.M r\right)$, transformed to standard scores, were used.

For the detection of any kind of relationship between the morphometric variables and the climatic data, Pearson's correlations with Bonferoni's correction (Rice, 1989) were performed between each climatic variable (transformed to standard scores) and each morphometric parameter (transformed to its natural logarithm). The Euclidean distances of the climatic parameters between the sampled localities were calculated with the SYSTAT computer program and tested for any relation with the Mahalanobis distances based on morphometric data of the 24 populations studied using Mantel's (1967) test.

\section{Statistical analysis of isoenzymic variation}

Observed or expected heterozygosity, proportion of polymorphic loci for each population, mean alleles per locus, genetic distances (Nei, 1978), Hardy-Weinberg equilibrium and $F$-statistics (Wright, 1978) were calculated using BIOSYS-1 (Swofford \& Selander, 1981). Deviations from the genotype frequencies expected from panmictic populations were tested with chisquared tests using Levene's (1949) correction for small sample size.

To compare the degree of differentiation within and between populations, $G$-statistics were used from the NEGST computer program (Chakraborty et al., 1982). Populations (localities) were considered grouped into demes (N.W. Greece, W. Greece, east continental Greece, W. Pelopennesos, S. Peloponnesos, Karytaina, E. Peloponnesos; every population of every island was considered separately apart from Crete which was divided into E. Crete and W. Crete), demes into areas (continental Greece, Peloponnesos, island of Evia, 
island of Crete and the rest of the islands separately) and areas into regions (continental Greece plus Peloponnesos and islands) according to geographical and climatic characteristics.

To investigate the genetic relationship between the examined populations a dendrogram was constructed, based on the allele frequencies, using UPGMA cluster analysis from the BIOsYs-I computer program. Furthermore, to find out which loci contributed mainly to the differentiation between the populations, a correspondence analysis was performed using the NTSYS computer program.

Number of alleles per locus, the percentage of polymorphic loci, the observed $(\mathrm{Ho})$ and expected heterozygosity $(\mathrm{He})$ and allele frequencies were each correlated with the climatic characteristics of each region using Bonferoni's correction to correct for the number of performed comparisons.

To investigate any kind of dependence of allele frequencies of a particular locus at one location on the frequency of that same locus at other nearby locations spatial autocorrelation analysis (Moran's $I$ autocorrelation coefficient) with the SAAP-43 computer program (Wartenberg, 1989) was performed.

To find out if there were any correlations between the genetic and morphological variation the multivariate coefficient of variability

$\mathrm{CV}_{\mathrm{p}}=100 \sqrt{\frac{\Sigma S x}{\Sigma M x}}$

(Sx $=$ variance of each morphometric variable, $M x=$ mean squared) was correlated with the degree of expected heterozygosity or/and the mean number of alleles per locus. The correlation of the matrices of genetic distances with Mahalanobis' distances was also tested using Mantel's test.

To investigate any kind of correlation between the geographic distance, genetic distance and climatic distance we compared the matrices of Nei's genetic distance, geographic distance and climatic distance using Mantel's (1967) test.

\section{Results}

\section{Morphological variation}

Interpopulational size variation was conspicuous. The mean shell largest diameters $(D)$ of the 24 samples ranged from $29 \mathrm{~mm}$ (sample from Siteia, island of Crete) to $39 \mathrm{~mm}$ (Zaharo, Peloponnesos) and the mean shell height $(H)$ from $20 \mathrm{~mm}$ (Siteia) to $27 \mathrm{~mm}$ (sample from Zaharo). Thus the mean size of the largest population was nearly one-third to one-quarter larger than the mean size of the smallest population. On the other hand, the size variation within populations was far less conspicuous as indicated by coefficient of variation $(\mathrm{CV} \%)$ values of $D, d i, W, H, T$ and $A p$ which ranged from 4 per cent to 10 per cent. (The table with detailed calculations of shell characters is available upon request.)

Variation in shell shape was less conspicuous than size variation. The $H / D$ ratio ranged from 0.62 (sample from Cyprus) to 0.72 (Preveza in N.W. Greece).

Shells were usually brown-yellowish and in most cases had five dark bands, apart from those from Preveza. Some populations had less than five bands (three to 14 individuals per population) and in the majority of them some of the bands were fused.

Discriminant analysis (DA) showed that there was considerable overlap among the groups. They were not clearly separated even though the discrimination was statistically significant. The variables which mainly contributed to the first discriminant function (squared canonical correlation 0.98 per cent) were shell height $(H)$ and for the second discriminant function (squared canonical correlation 0.94 per cent) shell aperture area $(A p)$. Classification results of DA showed that only 42.9 per cent of known groups were correctly classified. More precisely, the predicted group membership in percentages showed that the populations from Nafpaktos, Kamena Vourla and Kandanos (island of Crete) constituted homogeneous groups (100 per cent) whereas those from Halkida (island of Evia) and Karavas (W. Peloponnesos) were heterogeneous (0-10 per cent). Populations from Igoumenitsa (N.W. Greece), Athens, Peloponnesian populations (Nafplio, Glykovrysi, Zaharo and Karytaina), Irakleion and Siteia (island of Crete) and Cyprus island constituted more or less homogeneous groups at the level of 40-50 per cent and the rest of the samples at the level of 20-40 per cent.

The first $(H, 32$ per cent $)$ and the second factor $(d i$, 25 per cent) as well as the first with the third $(A p, 24$ per cent) factor of PCA of transformed morphometric characters separated eight groups according to their geographic proximity (Fig. 2a) except for Nafpaktos, Kandanos and Karavas which constituted three separate groups. The other five groups consisted of populations from Crete (except Kandanos region), Hios and Cyprus island, populations from W. Peloponnesos, populations from E. Greece (Athens, Lamia and Evia-Halkida and Karystos), populations from N.W. Greece, and populations from Glykovrysi (Peloponnesos) and Paros island. ANOVA tests confirmed that members of each group did not differ significantly in factors I and II of PCA. Although Kamena Vourla seemed to form a separate group, Fisher's 

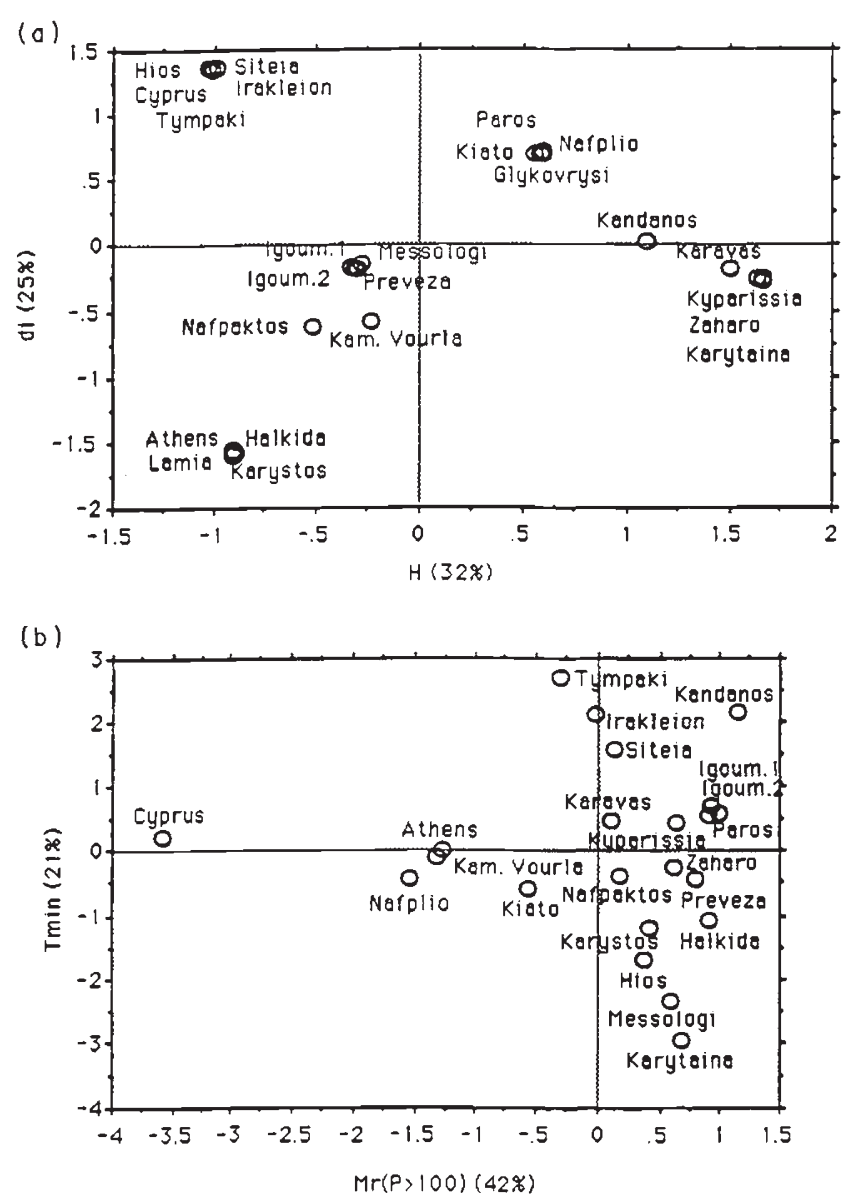

Fig. 2 (a) Distribution of populations on factor I and II scores of principal component analysis based on morphometric data of the shell characteristics in Helix aspersa. (b) Distribution of populations on factor I and II scores of principal component analysis based on climatic data in Greece and Cyprus.

L.S.D. test showed that it belonged to the same group as populations from N.W. Greece.

UPGMA cluster analysis based on Mahalanobis' distances was consistent with PCA results except for the separate groups of Kamena Vourla which was clustered with the rest of the neighbouring populations of E. Greece, Nafpaktos with the rest populations of N.W. Greece and Kandanos with the populations of W. Peloponnesos (Fig. 3).

The first factor $(M r, 42$ per cent) of PCA of transformed climatic data distinguished three groups: the sample from Cyprus, samples from E. Greece and the rest of the samples, which constituted a third group (Fig. 2b).

According to the first (number of shell bands) $(67.7$ per cent) and the second factor (fusion of bands) (31.2 per cent) of PCA using the qualitative data of the shell

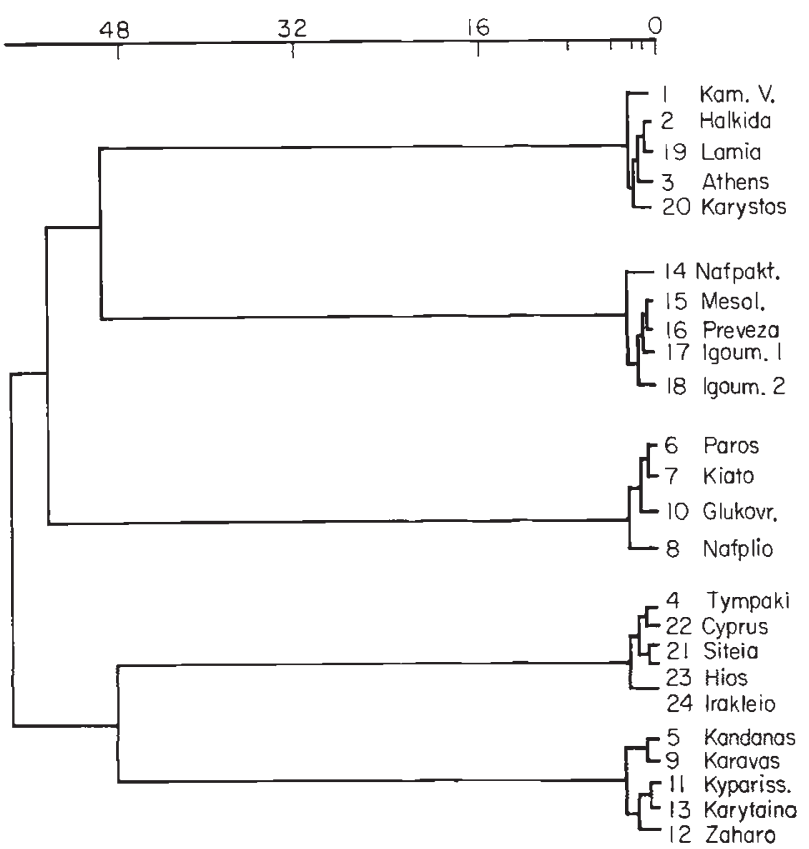

Fig. 3 UPGMA cluster analysis using Mahalanobis' distances between the morphometric characters of populations of Helix aspersa.

of $H$. aspersa, Preveza constituted a separate group because of the absence of bands in some of the snails of this region.

A correlation was only found between the shell thickness and the annual precipitation $(r=-0.365$, $P<0.01)$ and between the greatest shell diameter $(D)$, the aperture area $(A p)$ and the mean minimum annual monthly temperatures $\quad(r=-0.422, \quad P<0.001$; $r=-0.509, \quad P<0.001, \quad$ respectively). Significance values were adjusted with the sequential Bonferroni's procedure (Rice, 1989) to take into consideration that 42 tests were performed.

\section{Biochemical polymorphism}

A high degree of genetic variation was found in all populations (up to five alleles were found in most of the loci) except for three loci ( $\alpha G P D H, P M I, S O D)$ which were monomorphic in all populations examined.

The percentage of polymorphic loci (a locus was considered polymorphic if the frequency of the most common allele did not exceed 0.99 ) ranged from 33.3 per cent to 66.7 per cent and the mean expected heterozygosity per locus from 0.152 to 0.254 . (The table with the allele frequencies at each locus in each population is available upon request.)

Most of the populations were found to be significantly different from Hardy-Weinberg equilibrium in the loci EST-D, $M D H-1, P G M-1$, and $P G M-2$. In most 
of the cases this disagreement was caused by heterozygote deficiency (Table 3 ).

Coefficients of genetic identity and distance (Nei, 1978) were calculated for all pairwise combinations of the 24 populations. Pairwise Nei's genetic distances $(N=276)$ between all populations had a mean of $0.038 \pm 0.002$ and ranged from 0.001 to 0.131 .

The genetic diversity for the populations examined was further investigated with Wright's (1978) $F$ statistics $\left(F_{\mathrm{IS}}, F_{\mathrm{IT}}, F_{\mathrm{ST}}\right)$ (Table 4$) . F_{\mathrm{ST}}$ values provide an estimate of the differentiation between populations. The mean value of $F_{\mathrm{ST}}(0.128)$ indicated a low to moderate degree of differentiation, whereas the $F_{\text {IS }}$ and $F_{\text {IT }}$ values showed that there was a high degree $(>0.25)$ of intrapopulation differentiation.

Estimates of the coefficients of relative gene diversity ( $G$-statistic) are shown in Table 5 . There was considerable differentiation only within localities $(87$ per cent was explained by differences within localities). It must be pointed out that $G P D-1$ and $P G M-2$ had shown greater values of differentiation in the higher levels (Table 5).

The dendrogram constructed using UPGMA cluster analysis based on the Nei's genetic identity showed that populations from N.W. Greece exhibit a high degree of differentiation from the rest of the populations (Fig. $4 \mathrm{a})$. The genetic relationships between populations was further examined using correspondence analysis. The results from the latter analysis indicated that the populations of northwestern Greece were differentiated as with UPGMA cluster analysis, based on Nei's genetic identity. The most important contributions to inertia described by factor 1 (27.8 per cent) were those of $G P D-1 B$ and $L A P-1 D$ which were found in high frequency in western Greece but were absent or present at very low frequency $(>0.1)$ in eastern Greece and the islands. This factor permitted a first differentiation of the group of populations from N.W. Greece which were characterized by high frequency of those two alleles. Axis 2, with an explanatory power of 20 per

Table 3 Values of heterozygote deficiency

\begin{tabular}{|c|c|c|c|c|c|c|c|c|c|c|}
\hline Localities & $E S T-D$ & EST-1 & $E S T-2$ & $G P D-1$ & $L A P-1$ & $L D H-I$ & $M D H-1$ & $P G M-1$ & $P G M-2$ & $P G I-1$ \\
\hline goumenitsa-1 & $-0.711^{*}$ & 0 & -0.124 & 0.014 & -0.112 & 0.014 & $-0.567^{*}$ & $-0.462^{*}$ & $-1.000^{*}$ & 0 \\
\hline Igoumenitsa-2 & $-0.376^{*}$ & 0.029 & -0.125 & 0.166 & $-0.345^{*}$ & - & $-0.587^{*}$ & $-0.660^{*}$ & $-1.000^{*}$ & $-0.486^{*}$ \\
\hline Preveza & $-0.552^{*}$ & 0.007 & $-0.163^{*}$ & -0.252 & $-0.125^{*}$ & -0.048 & $-0.156^{*}$ & 0 & $-0.660^{*}$ & 0 \\
\hline Mesolongi & $-0.952^{*}$ & $-0.657^{*}$ & -0.175 & - & $-1.000^{*}$ & $-0.364^{*}$ & $-1.000^{*}$ & $-0.486^{*}$ & $-1.000^{*}$ & $-0.788^{*}$ \\
\hline Nafpaktos & $-0.736^{*}$ & $-0.167^{*}$ & -0.157 & - & -0.112 & 0.044 & $-0.723^{*}$ & $-0.478^{*}$ & $-1.000^{*}$ & 0.041 \\
\hline Athens & $-0.439^{*}$ & $-0.691^{*}$ & $-0.312^{*}$ & 0 & $-0.271^{*}$ & $1.000^{*}$ & $-0.604^{*}$ & $-0.791^{*}$ & - & $-1.000^{*}$ \\
\hline Halkida & $-0.369^{*}$ & 0.060 & -0.231 & $-0.715^{*}$ & $-0.475^{*}$ & $-0.313^{*}$ & 0.044 & 0.076 & $-0.909^{*}$ & $-0.649^{*}$ \\
\hline Karystos & -0.268 & $-0.767^{*}$ & $-0.076^{*}$ & - & 0.019 & $-0.641^{*}$ & $-0.633^{*}$ & $-1.000^{*}$ & $-1.000^{*}$ & - \\
\hline Lamia & -0.183 & -0.154 & 0.074 & - & $-0.386^{*}$ & $-0.374^{*}$ & $-0.915^{*}$ & $-0.791 *$ & - & $-1.000^{*}$ \\
\hline Kam. Vourla & $-0.440^{*}$ & 0.091 & 0.065 & $-0.474 *$ & $-0.244^{*}$ & 0.060 & $-0.879^{*}$ & $-0.733^{*}$ & $-0.729^{*}$ & $-0.458^{*}$ \\
\hline Paros & $-0.294^{*}$ & $-0.416^{*}$ & $-0.174 *$ & 0 & 0.069 & $-0.375^{*}$ & $-0.652^{*}$ & $-1.000^{*}$ & - & -0.292 \\
\hline Kiato & $-0.366^{*}$ & -0.139 & -0.257 & - & -0.390 & -0.283 & $-0.381^{*}$ & $-1.000^{*}$ & - & $-0.484^{*}$ \\
\hline Nafplio & $-0.175^{*}$ & -0.162 & $-0.137^{*}$ & - & -0.358 & 0.092 & $-0.485^{*}$ & $-0.297^{*}$ & $-1.000^{*}$ & $-0.478^{*}$ \\
\hline Karavas & $-0.469^{*}$ & 0.014 & $-0.308^{*}$ & -0.087 & $-0.484^{*}$ & 0.014 & $-0.201 *$ & $-0.791 *$ & $-1.000^{*}$ & $-0.532^{*}$ \\
\hline Glykovrysi & $-0.696^{*}$ & 0 & $-0.408^{*}$ & -0.050 & 0.052 & $1.000^{*}$ & -0.172 & $-1.000^{*}$ & - & $-0.478^{*}$ \\
\hline Kyparissia & $-0.367^{*}$ & -0.029 & -0.080 & 0.044 & $-0.403^{*}$ & 0 & $-0.431^{*}$ & $-0.729^{*}$ & $-1.000^{*}$ & -0.220 \\
\hline Zaharo & $-0.286^{*}$ & 0.017 & -0.101 & -0.007 & $-0.453^{*}$ & 0 & $-0.661^{*}$ & 0.017 & - & $-1.000^{*}$ \\
\hline Karytaina & $-0.804^{*}$ & 0.014 & $-0.138^{*}$ & - & -0.084 & - & $-0.399^{*}$ & $-0.606^{*}$ & $-0.385^{*}$ & - \\
\hline Tympaki & $-0.692^{*}$ & -0.347 & $-0.082^{*}$ & - & $-0.204^{*}$ & $-0.445^{*}$ & $-0.549^{*}$ & $-0.649^{*}$ & 0.014 & 0.019 \\
\hline Kandanos & $-0.497^{*}$ & -0.083 & $-0.277^{*}$ & - & $-0.536^{*}$ & -0.260 & $-0.477^{*}$ & $-1.000^{*}$ & - & $-0.630^{*}$ \\
\hline Siteia & $-0.562^{*}$ & $-0.689^{*}$ & -0.016 & 0.018 & $-0.379^{*}$ & $-0.655^{*}$ & $-0.854^{*}$ & $-1.000^{*}$ & - & 0.009 \\
\hline Irakleion & 0.034 & - & $0.011^{*}$ & 0.062 & $-0.423^{*}$ & - & $-0.597^{*}$ & - & - & - \\
\hline Hios & $-0.255^{*}$ & 0.145 & -0.025 & 0.114 & $-0.831^{*}$ & - & $-0.584^{*}$ & - & - & - \\
\hline Cyprus & $-0.516^{*}$ & - & $-0.195^{*}$ & - & $-0.657^{*}$ & - & $-0.847^{*}$ & 0 & $-1.000^{*}$ & 0 \\
\hline Heterozygote def. $\%$ & 96 & 62 & 87 & 96 & 67 & 87 & 83 & 96 & 75 & 79 \\
\hline $\begin{array}{l}\text { Percentage of local- } \\
\text { ities in agreement } \\
\text { with H.W. }\end{array}$ & 13 & 67 & 50 & 50 & 33 & 42 & 8 & 17 & 4 & 33 \\
\hline
\end{tabular}

*Localities in disagreement with H.W. equilibrium $(P<0.05)$. 
cent, accentuated the differentiation of the population of Karytaina which was characterized by a high frequency of the alleles $P G M-2 B$ and $P G M-2 D$ (Fig. 4b). Axis 3 , with an explanatory power of 10 per cent, accentuated the differentiation of the populations from N. Peloponnesos (Kiato, Nafplio), Athens, Karystos and the island of Hios which were characterized by a high frequency of the allele $I D H-I B$.

To determine whether climatic parameters were correlated with allozymic variation, seven climatic variables were used. Frequencies of individual alleles

Table 4 Results of Wright's $F$-statistics

\begin{tabular}{|c|c|c|c|c|}
\hline $\begin{array}{l}\text { No. of } \\
\text { alleles }\end{array}$ & Locus & $F_{\text {IS }}$ & $F_{\text {IT }}$ & $F_{\mathrm{ST}}$ \\
\hline 2 & $A A T-I$ & -0.059 & -0.002 & 0.053 \\
\hline 4 & $E S D$ & 0.460 & 0.533 & 0.136 \\
\hline 4 & EST-I & 0.227 & 0.311 & 0.108 \\
\hline 5 & $E S T-2$ & 0.130 & 0.196 & 0.076 \\
\hline 3 & $G P D-1$ & 0.035 & 0.514 & 0.496 \\
\hline 3 & $I D H-I$ & 0.202 & 0.278 & 0.095 \\
\hline 5 & $L A P-I$ & 0.311 & 0.408 & 0.141 \\
\hline 3 & $L D H-1$ & 0.281 & 0.341 & 0.083 \\
\hline 4 & $M D H-1$ & 0.575 & 0.595 & 0.047 \\
\hline 3 & $P G M-1$ & 0.665 & 0.677 & 0.034 \\
\hline 4 & $P G M-2$ & 0.746 & 0.816 & 0.227 \\
\hline 4 & $P G I-I$ & 0.484 & 0.502 & 0.035 \\
\hline 44 & Mean & 0.367 & 0.448 & 0.128 \\
\hline
\end{tabular}

gave significant correlations with total annual precipitation $(\mathrm{P})$ at the level of $P<0.01(E S T-D C(r=0.674)$, EST-DD $(r=0.726), G P D-1 A(r=-0.753), G P D-1 B$ $(r=0.762), \quad L A P-1 B \quad(r=-0.506), \quad L A P-1 D$ $(r=0.505)$. No correlation was found, after Bonferroni's correction, between the number of alleles per locus, the percentage of polymorphic loci, the observed and expected heterozygosity and the climatic variables examined.

No correlation was found between the genetic and morphological variability concerning (1) the relation between the multivariate coefficient of variation $\left(\mathrm{CV}_{\mathrm{p}}\right)$ and the mean number of alleles per locus or the expected heterozygosity, and (2) the relation between genetic and Mahalanobis distances.

To investigate any kind of correlation between morphological, genetic, geographic and climatic distances, a Mantel's test was performed between the above matrices. When the island populations were included no such correlation was found. When only continental populations were included, Mantel's test employing 1000 random permutations indicated that the significant correlations among those sampled were between geographic distances and Nei's genetic distances $(r=0.51)$, between genetic distances and Mahalanobis distances $(r=0.39)$, and between Nei's genetic distances and climatic distances $(r=0.34)$ (Table 6).

To investigate if this correlation between the genetic and the geographic distances was caused by the gene flow, we estimated the migration rate between the

Table 5 Coefficients of relative gene diversity (Gs) at various levels of nested classification of gene frequency data of $H e l i x$ aspersa

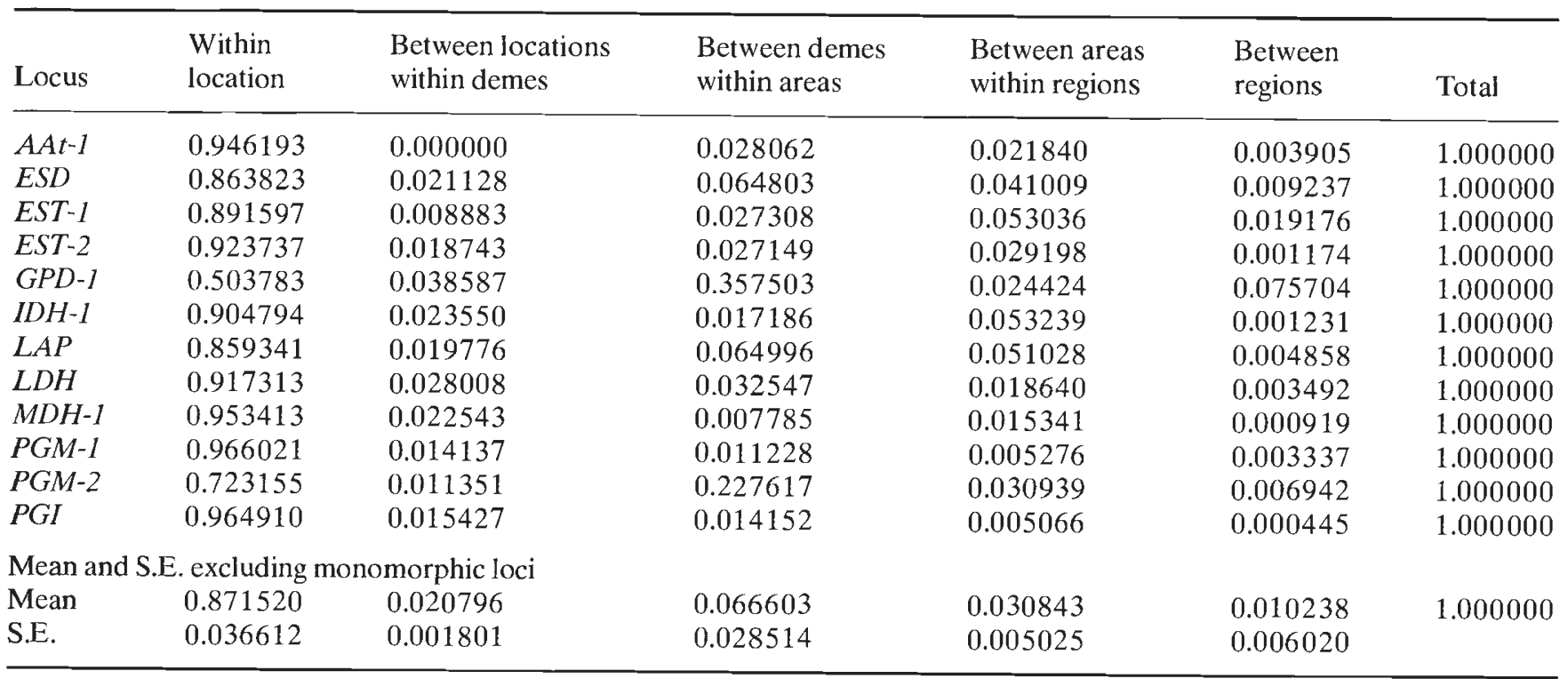


(a)

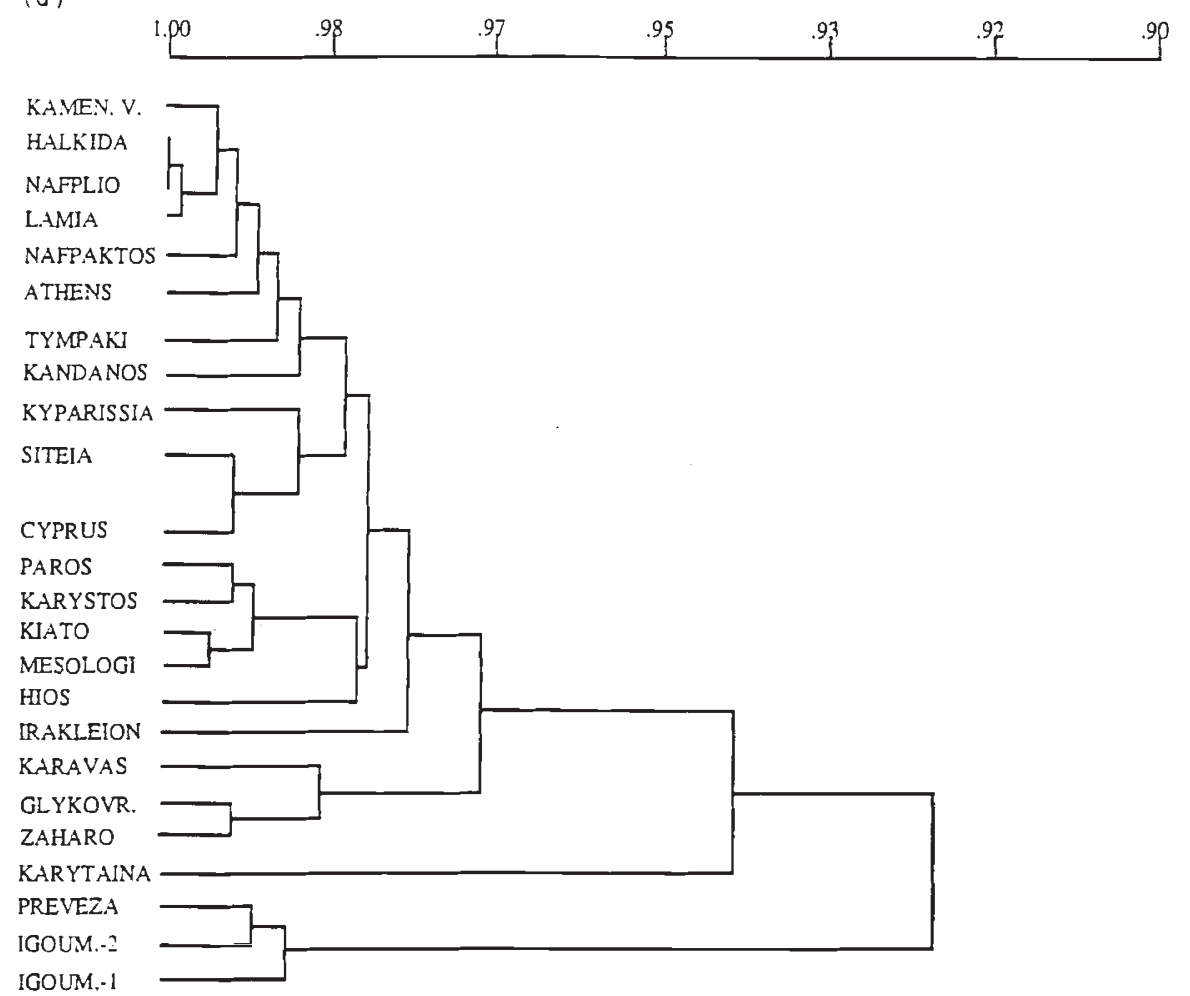

(b)

Fig. 4 (a) UPGMA cluster analysis using Nei's genetic identity between populations of Helix aspersa. (b) Simultaneous representation of alleles and populations on principal plane (axis 1 horizontal, axis 2 vertical) of the correspondence analysis based on the 42 more frequent alleles.

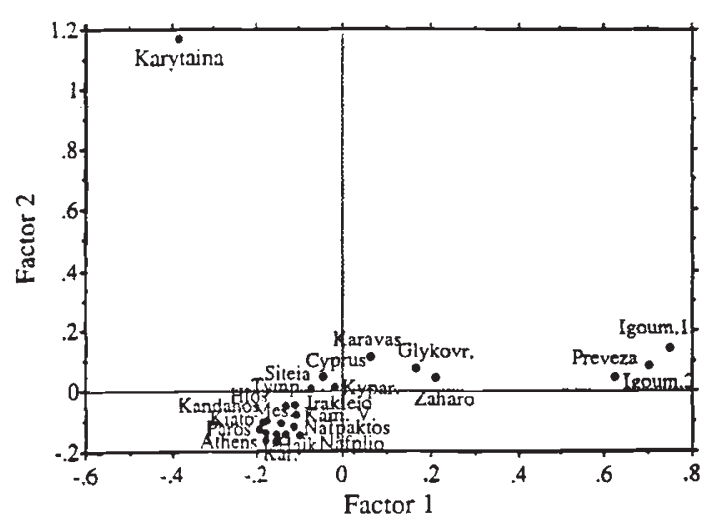

populations from the formula

$N_{\mathrm{m}}=\frac{1 / F_{\mathrm{ST}}-1}{4}$,

and it was found to be 1.7 propagules per generation. Furthermore, spatial autocorrelation analysis between the continental populations showed that Moran's I autocorrelation coefficient was significantly positive in adjacent distances but negative in greater distances (Fig. 5) showing that allele frequencies of a particular locus at one location were dependent on the frequency of that same locus at other nearby locations.

\section{Discussion}

The study of the morphometric characteristics of the shells jointly showed that there was considerable multivariate intrapopulation variation as revealed by discriminant analysis although the coefficient of variability $(\mathrm{CV} \%)$ was low for each character separately.

$\mathrm{PC}$ analysis revealed that most of the populations were grouped according to their geographical origin only when Burnaby's size correction was performed. The clustering of the populations using UPGMA cluster analysis based on Mahalanobis distances with the six characters examined jointly (Fig. 2), was consistent 
Table 6 Coefficient of correlation between the matrices of climatic, genetic, Mahalanobis and geographic distances between the continental populations of Helix aspersa from Greece

\begin{tabular}{lllll}
\hline & Climate & Genetics & Mahalanobis & Geography \\
\hline Climate & - & $0.343^{*}$ & -0.129 & Not done \\
Genetics & & - & 0.125 & $0.51^{* *}$ \\
Mahalanobis & & & - & $0.39^{* *}$ \\
Geography & & & & - \\
\hline
\end{tabular}

Significance was determined from Mantel's test after 1000 permutations.

${ }^{*} P<0.05,{ }^{* *} P<0.01$.

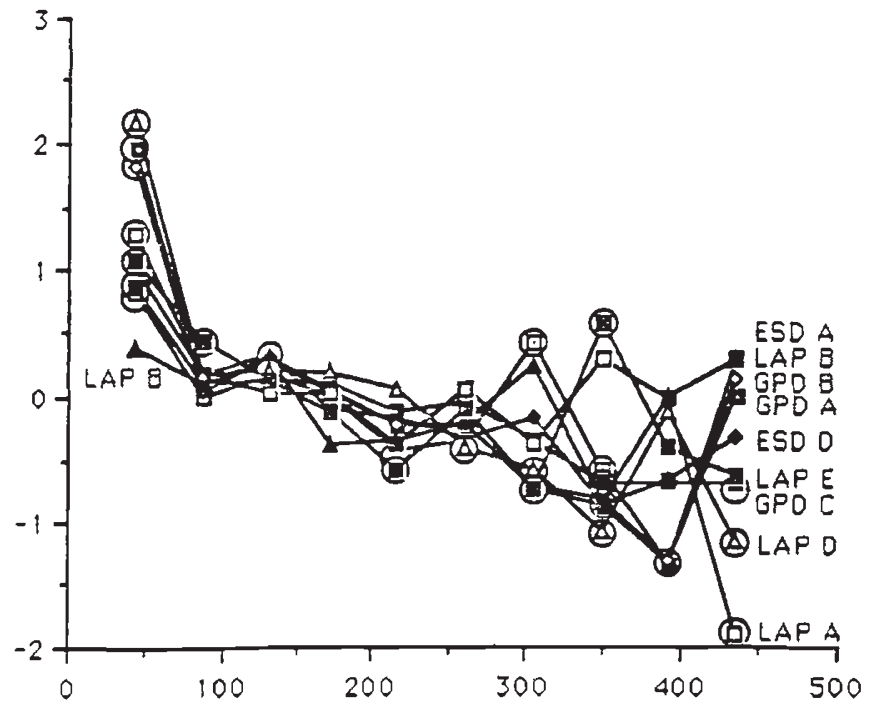

Fig. 5 Correlograms for five artificially generated variables intended to simulate distinct patterns of geographic variation. Abscissa: distance in kilometres. Ordinate: Moran's autocorrelation coefficient $I$. Significant autocorrelation coefficients $(P<0.05)$ are indicated by open circles.

with P.C.A., except for the samples from Nafpaktos, Kandanos, Karavas and Glykovrisi which in this analysis were clustered with their adjacent regions. These results had not been apparent when Burnaby's size correction had been omitted (M. Lazaridou-Dimitriadou et al., in press) possibly because when size correction is not used intracluster size variation masks intercluster variation.

A noticeable correlation with climatic conditions also existed in individual characters, such as the thickness of the shell, the aperture area and the largest shell diameter. The largest shell diameter and the aperture area were larger in regions with lower minimum temperatures. Differences in the shell thickness have been reported previously and found to be related to aridity (Machin, 1975; Pollard, 1975; Bar, 1978). Knowing that the aperture is the main site of water loss even when the mantle edge regulates evaporation (Gebhardt-Dunkel, 1953; Machin, 1967), in the present study it seems that aperture area and the largest shell diameter are both negatively related to the mean minimum annual monthly temperatures which may indicate that larger snails do not survive as well in warmer conditions. It must be noted that Cook \& O'Donald (1971) and Knights (1979) found that smaller snails survived better in unshaded or warmer conditions.

Biochemical polymorphism of $H$. aspersa varied greatly from one population to another, as did morphological polymorphism. The $G$-statistics analysis showed that heterogeneity was considerable at the intrapopulation level as Selander \& Ochman (1983) also found in $H$. aspersa in California. The percentage of polymorphic loci ranged from 33 per cent to 67 per cent which was a higher value than the ones found by Bleakney et al. (1989) in the same species. Expected heterozygosity $(\mathrm{He})$ was very high in all populations studied and it was higher than average for molluscs $(0.148)$ but did not reach the values of 0.644 found for Modiulus auriculatus (Selander \& Ochman, 1983) or 0.635 for Cerithium coeroleum (Nevo et al., 1984). The same degree of heterozygosity was reported by Madec (1991b) for the same species. This high degree of heterozygosity may be caused by spatiotemporally heterogeneous environments.

Concerning Hardy-Weinberg equilibrium, significant deviation was found in most of the loci and in most of the populations. This deviation was mainly caused by heterozygote deficiency (Table 3 ). Although Lessios (1992) showed that the statistical procedures used and the interpretation of their results are often flawed, such heterozygote deficiencies have been demonstrated by many studies on natural populations of several marine bivalves (Zouros \& Foltz, 1984), 
crustaceans (Beck \& Price, 1985) and other invertebrates (Crouau-Roy, 1988). In our case we cannot evaluate if this deficiency was caused by the possibility of having null alleles, sampling of more than one genetically isolated population (the Wahlund effect), or/and assortative mating (or low hybrid survivorship). However, self-fertilization cannot be taken into account as $H$. aspersa generally reproduces by crossed and reciprocal fertilization. Self-fertilization may be possible in isolation from hatching (Lucarz, 1991) but only after injecting prostate homogenates or physiological saline. The most probable explanation is the structuring of the populations (the individuals are not homogeneously distributed but occur in more or less well-defined clusters), and the fact that this animal is iteroparous (Lazaridou-Dimitriadou \& Kattoulas, 1981; Lazaridou-Dimitriadou \& Bailey, 1991) and its dispersal ability is low and so inbreeding between relatives is possible in the same cluster.

No correlation was found between the multivariate coefficient of variation of the morphological variables and the expected heterozygosity or the mean number of alleles per locus. This may be because although both morphological and genetic variables seem to be correlated to individual environmental factors, the climatic factors jointly or other factors may influence genetic variation in a different way. This relationship between morphological and genetic variation has not been found in poikilothermic species such as fish (King, 1985) or other snails (Booth et al., 1990).

The high frequency of two alleles, $G P D-I B$ and $L A P-1 D$, in western Greece may be related to climatic factors (e.g. to precipitation) as their frequencies were found to be significantly correlated to mean annual precipitation. Additionally, it must be noted that the sample from Preveza (N.W. Greece) differed in the qualitative characters of its shell (in the number and the presence of bands). The fact that no correlation was found between the overall genetic variation, as this was calculated by the expected heterozygosity, and the climatic variables, although this correlation was found for individual allele frequencies, is an indication that selective forces may influence the genetic variation of those populations. Furthermore, Crook (1982) reported that southern populations of $H$. aspersa in the U.K. were more polymorphic than northern ones for the LAP enzyme system. Geographic differentiation for some loci was also reported by Johnson (1976) in C. nemoralis and by Selander \& Ochman (1983) in $H$. aspersa. Madec (1991a) also found in $H$. aspersa a change in the majority of alleles of two loci $(M D H-1$, $P G M-s)$ from one locality to the other. Furthermore, the fact that a unique allele $P G M-2 B$ was found only in the Karytaina population at high frequency may be due to a mutation which appeared in this population and did not spread to others because of isolation; Karytaina is found at $555 \mathrm{~m}$ in altitude. We must also take into consideration that in $C$. nemoralis in Spain the frequency of the allele $C$ in locus $P G M-2$ was found to be related to altitude (Mazon et al., 1988) and that Karytaina is the only locality that had $555 \mathrm{~m}$ altitude. To support such a relationship, a similar study must be done with $H$. aspersa sampled from different altitudes.

The results of correspondence analysis and the dendrograms produced by the UPGMA algorithm using Nei's identity showed that the degree of genetic identity was considerable among the populations studied, apart from the group of N.W. Greek populations $(I=0.88)$. This was also found with Wagner's cladogram (M. Lazaridou-Dimitriadou et al., in press). Nei's identity $(I)$ found between the populations of the regions from N.W. Greece and the rest of the populations was not as low as the one found by Madec (1991b) in Helix aspersa between the French populations and those from Algeria. We cannot support with the present results the contention that two geographical races exist, at least for the populations studied, or the existence of two forms $H$. aspersa aspersa and $H$. aspersa major (Chevallier, 1977).

The genetic differentiation as well as the morphological one (PCA and UPGMA cluster analysis based on the Mahalanobis distances) between western and eastern Greek populations seems to be the result of at least two factors: geographical isolation (Pindus mountains) and climatic factors (Kotini-Zabaka, 1983) which favoured different genotypes in different regions. This was supported by the facts that genetic distances were correlated to the Euclidean climatic distances and Mahalanobis and genetic distances were correlated with geographic distances. Furthermore, it seems that the climate combined with the vegetation also influences the allele frequencies of other loci, e.g. the $I D H$ $B$ allele was found only in a specific zone which Quézel \& Barbéro (1985) characterized as a zone where a thermomediterranean type of vegetation dominates and especially Pinus halepensis forests.

Spatial autocorrelation in continental populations tended to decrease significantly with increasing distance for several loci (Fig. 5). It seems that the allele frequencies in one population were influenced by the allele frequencies of neighbouring populations. This means that gene flow may play an important role in the genetic diversity among the populations which was also supported by the high value of migration rate as calculated by the value of $F_{\mathrm{ST}}$ and by the significant correlation between genetic distances and geographical distances. This pattern disappeared when the island populations were included in the above analyses. It 
seems that the genetic structure of continental populations follows a pattern of increased differentiation with increasing distance which was not apparent in the island populations. Many different forces interfere in the genetic differentiation of the island populations. If only stochastic forces (e.g. founder effect followed by genetic drift) played an important role in their genetic structure then the island populations would be characterized by a lower degree of heterozygosity and a higher degree of genetic distance from the continental populations; this was not found. This species, being edible, has been introduced by humans to many islands in a random way; its populations on an island may either originate from a small sample coming from any region or may have evolved from the introgression of the introduced and the pre-existing populations.

In conclusion, the correlation that exists between individual allele frequencies and climatic variables, the high value of migration rate and the results of spatial autocorrelation analysis indicate that selective forces mainly generate the pattern of genetic diversity found in the continental populations in Greece. However, in the island populations the pattern seems to be influenced mainly by stochastic forces.

\section{Acknowledgements}

We thank Dr H. Lessios (Smithsonian Tropical Research Institute, Panama) for reading this paper and providing helpful comments. Thanks are also due to $\mathrm{D}$. Sioula, E. Alpogianni and N. Kifonidis for their technical help.

\section{References}

ALbuQuerque DE matos, R. M. 1984. Genetics of shell ground colour in Helix aspersa. I. Colour locus, uniform and their interactions. Heredity, 53, 11-20.

ALBUQUERQUE DE MATOS, R. M. 1989. Contribution of genetics to snail farming and conservation. In: Slugs and Snails in World Agriculture, BCPC monograph, no. 41, pp. 11-18.

ASHTON, G., BRADEN, C. AND BRADEN, A. 1961. Serum-globuline polymorphism in mice. Austr. J. Exp. Biol. Med. Sci., 14, 248.

BAR, Z. 1978. Variation and natural selection in shell thickness of Theba pisana along climatic gradients in Israel. $J$. Moll. Stud., 44, 322-326.

BAUR, B. 1984. Dispersion, Bestandesdichte und Diffusion bei Arianta arbustorum (L.) (Mollusca, Pulmonata). Ph.D Thesis, University of Zurich.

BECK, M. L. AND PRICE, J. O. 1985. Genetic variation and differentiation in Armadillidium vulgare (Isopoda: Oniscoidea). Genetica, 66, 169-171.

BLEAKNEY, M. M., FLEMING, C. C. AND MARKS, R. J. 1989. Genetic and phenotypic variation in allopatric populations of Helix aspersa (Müller): a preliminary report. In: Slugs and Snails in World Agriculture, BCPC monograph, no. 41, pp. 319-326.

BOOTH, C., WOODRUFF, D. AND GOULD, S. 1990. Lack of significant associations between allozyme heterozygosity and phenotypic traits in the land snail Cerion. Evolution, 44, 210-213.

BURNABY, T. P. 1966. Growth-invariant discriminant functions and generalized distances. Biometrics, 22, 96-110.

CHAKRABORTY, R., HAAG, M., RYMAN, N. AND STAHL, G. 1982. Hierarchical gene diversity analysis and its application to brown trout population data. Hereditas, 97, 17-21.

CHevalier, H. 1977. La variabilité de l'escargot Petit-gris Helix aspersa Müller. Bull. Mus. Nat. His. Nature $3^{r}$ série, 448, 425-442.

соок, L. M. 1965. Inheritance of shell size in the snail Arianta arbustorum. Genetics, 53, 415-425.

COOK, L. AND O'DONALD, P. 1971. Shell size and natural selection in Cepaea nemoralis. In: Creed, E. R. (ed.), Ecological Genetics and Evolution, pp. 93-108.

CROOK, S. J. 1982. Genetic studies of allozyme variation in leucine aminopeptidase in the land snail Helix aspersa (Müller). J. Moll. Stud., 48, 362-365.

CROUAU-ROY, B. 1988. Genetic structure of cave-dwelling beetle populations: significant deficiencies of heterozygotes. Heredity, 60, 321-327.

GEBHARDT-DUNKEL, E. 1953. Die trocken resistenz bei Gehauseschnectier. Zool. Jb (Zool.), 64, 235-266.

HARALAMBIDIS, S., PAPAZACHARIADOU, M., LAZARIDOU-DIMITRIADOU, M., HIMONAS, C. AND KATTOULAS, M. 1985. Contribution to the parasitological study of the commercialized snails of Greece. 1. Parasites of the snails Helix aspersa Müller and Helix lucorum L. from the Greek mainland. Biologia Gallo-Hellenica, X, 143-148.

JOHnson, M. S. 1976. Allozymes and area-effects in Cepaea nemoralis on the western Berkshire downs. Heredity, 36, 105-121.

KING, D. 1985. Enzyme heterozygosity associated with anatomical character variance and growth in the herring (Clupea harengus). Heredity, 54, 289-296.

KNIGHTS, R. W. 1979. Experimental evidence for selection on shell size in Cepaea hortensis (Müll). Genetica, 50, 51-60.

KOTINI-ZABAKA, s. 1983. Contribution to the monthly study of the climate of Greece. Ph.D Thesis, Aristotle University of Thessaloniki.

LAZARIDOU-DIMITRIADOU, M. AND BAILEY, S. E. R. 1991. Growth, reproduction and activity rhythms in two species of edible snails, Helix aspersa and Helix lucorum, in non-hour light cycles. J. Zool. Lond., 225, 381-391.

LAZARIDOU-DIMITRIADOU, M., KARAKOUSIS, Y. AND STAIKOU, A. Morphological and genetic variation in Greek populations of the edible snail Helix aspersa Müller, 1774 (Gastropoda: Pulmonata) A preliminary survey. In: Haroisewych, M. C. and S. Tillier (eds). Molecular Techniques and Moluscan Phylogeny: Proceedings of a symposium held at the IIth International Malacological Congress, Siena, Italy. The Nautilus, Supp. 2.

lazaridou-Dimitriadou, M. AND katToulas, m. 1981. Contribution a l'étude de la biologie et de la croissance des escargots commercialisés en Grèce: Eobania vermiculata (Müller) et Helix aspersa Müller. Haliotis, 11, 129-137. 
LAZARIDOU-DIMITRIADOU, M., KATTOULAS, M. AND STAIKOU, A 1983. Searching for the factors that provoke differences in the size and weight of snails (Helix aspersa Müller) from two different populations, one from the island of Krete and the other from Peloponnesos (Greece). J. Moll. Stud., 12A (Supp.), 89-93.

LEssios, H. A. 1992. Testing electrophoretic data for agreement with Hardy-Weinberg expectations. Mar. Biol., 112 , 514-523.

LEVENE, H. 1949. On a matching problem arising in genetics. Am. Math. Stat., 20,91-94.

LUCARZ, A. 1991. Evidence of an egg-laying factor in the prostatic secretions of Helix aspersa Müller. Comp. Bioch. Physiol, 100A, 839-843.

MACHIN, J. 1967. Structural adaptation for reducing water-loss in three species of terrestrial snails. J. Zool. Lond., 152, 55-65.

MACHIN, J. 1975. Water relationships. In: Fretter, V. and Peake, J. (eds) Pulmonates (I) Functional Anatomy and Physiology, Academic Press, London, pp. 105-163.

MADEC, L. 1989. Origine et importance des differances affectant la forme et la taille des oeufs chez l'escargot Petit-gris Helix aspersa Müller. Haliotis, 19, 143-152.

MADEC, L. 1991a. Variabilité enzymatique dans quelques populations naturelles de l'espèce Helix aspersa Müller. $C$. R. Acad. Sci. Paris, 313 (Série III), 339-344.

MADEC, L. 1991b. Genetic divergence in natural populations of the landsnail Helix aspersa Müller, 1774, J. Moll. St., 57, 483-487.

MADEC, L. AND DAGUZAN, J. 1987. Etude de quelques facteurs affectant la reproduction de l'escargot Petit-gris Helix aspersa Müller. Haliotis, 16, 77-91.

MAHALANOBIS, P. C. 1936. On the generalised distance in statistics. Proceedings of the National Institute of Sciences of India, 2, 49-55.

MANTEL, N. A. 1967. The detection of disease clustering and a generalized regression approach. Cancer Res, 27 , 209-220.

MAZON, L. I., VICAR1O, A., DE PANCORBO, M. A. M., AGUIRRE, A. I., ESTOMBA, A. AND LOSTAO, C. M. 1988. North/South differentiation in the distribution of Cepaea nemoralis in Spain. Heredity, 61, 189-197.

NEI, M. 1978. Estimation of average heterozygosity and genetic distance from a small number of individuals. Genetics, 89, 583-590.

NEVO, E., BEILES, A. AND BEN SCHOMO, R. 1984. The evolutionary significance of genetic diversity: ecological, demographic and life history correlated. In: Mani, G. S. (ed.), Evolutionary Dynamics of Genetic Diversity, Lecture Notes in Biomathematics, 53, 13-213.

PIANKA, E. R. 1988. Evolutionary Ecology. Harper and Row Publishers, London.

PILSBRY, H. A. 1939. Land Molluscs of North America (North of Mexico), Monograph 3, vol. 1, part 1, Academy of Natural Sciences, Philadelphia.

POLLARD, E. 1975. Differences in shell thickness in adult Helix pomatia $\mathrm{L}$. from a number of localities in southern England. Oecologia (Berl.), 21, 85-92.

QUEZEL, P. AND BARBERO, M. 1985. Carte de la végétation potentielle de la region Méditerranéenne. Feuille No. 1. Méditerranée orientale. Editions du Centre National de la Recherche Scientifique, Paris.

RICE, W. R. 1989. Analysing tables of statistical tests. Evolution, 43, 223-225.

RoHlF, F. J. 1990. Numerical Taxonomy and Multivariate Analysis System. Exeter software, N.Y.

SACCHI, C. F. 1958. Les Mollusques terrestres dans le cadre des relations biogéographiques entre l'Afrique du Nord et l'Italie. Vie et Milieu, 9, 11-52.

SELANDER, R. AND KAUFMAN, D. W. 1975. Genetic structure of the populations of the brown snail (Helix aspersa). I. Microgeographic ratiation. Evolution, 29, 385-401.

SELANDER, R. K. AND OCHMAN, H. 1983. Genetics and evolution. In: Rattazzi, M. C., Scandalios, J. and G. Whitt (eds), Isozymes: Current topics in Biological and Medical Research, vol. 10, Alan R. Liss, New York, pp. 93-123.

SMITH, I. 1968. Chromatographic and Electrophoretic Techniques, vol. 2, 2nd edn. William Heinemann Medical Books C.T.T., London.

SNEATH, P. AND SOKal, R. 1963. Principles of Numerical Taxonomy. W. H. Freeman, San Francisco.

SOKAL, R. R. AND ODEN, N. L. 1978. Spatial autocorrelation in biology. 1. Methodology. Biol. J. Linn. Soc., 10, 199-228.

SWOFFORD, D. L. AND SELANDER, R. B. 1981, BIOSYS-1: a FORTAN program for the comprehensive analysis of electrophoretic data in population genetics and systematics. J. Heredity, 72, 281-283.

WARTEnBerG, D. 1989. A Spatial Autocorrelation Analysis Program. Piscataway, N.Y.

WR1GHT, s. 1978. Evolution and the Genetics of Populations, vol. 4, Variability within and among Natural Populations, University of Chicago Press, Chicago.

zouros, E. AND FOLTZ, D. W. 1984. Possible explanations of heterozygote deficiency in bivalve molluscs. Malacologia, 25, 583-591. 